\title{
High-resolution monitoring of water temperature and oxygen concentration in Lake Murten (Switzerland)
}

\author{
Akram El Kateb $^{1} \cdot$ Andres Rüggeberg $^{1} \cdot$ Claudio Stalder $^{2} \cdot$ Christoph Neururer $^{1} \cdot$ Silvia Spezzaferri $^{1}$
}

\begin{abstract}
Lake Murten is located in the Lake District in western Switzerland and so far, it has been poorly investigated. The Environmental Service of Fribourg (SEn) has monitored this lake once a month for several years by water profiles (water temperature, $\mathrm{pH}$, dissolved oxygen, conductivity) at its deepest part. The SEn identified the stratification of water masses as one of the main causes for oxygen consumption in the hypolimnion. In the present study, a Lander System was deployed in Lake Murten from April to September 2015 at $20 \mathrm{~m}$ depth at the northwestern part of the lake to monitor water temperature and dissolved oxygen at higher resolution (30 s interval). These records were compared with time series of atmospheric parameters like atmospheric temperature, wind speed and precipitation. A clear correlation of lake temperatures with wind speed was observed during the Spring and Autumn. The water mass stratification evolved through the season and reached its peak during Summer, preventing surface turbulences to reach the deeper part $(20 \mathrm{~m})$ of the water column and to partially oxygenate the metalimnion.
\end{abstract}

Keywords Water parameters · Stratification · Monitoring $\cdot$ High-resolution $\cdot$ Lake Murten

\section{Introduction}

Thermal vertical water mass stratification is a well-known process in lakes. Atmospheric conditions, especially atmospheric temperature have a direct impact on water masses and their stratification. High air temperatures and solar radiation warm-up the mixed-surface layer (epilimnion), while the deeper water layer (hypolimnion) remains cold (Monismith and MacIntyre 2009). The thermal expansion of water has a strong effect on the water mass stratification creating a vertical density gradient (Read et al. 2011). Water stratification along a vertical profile prevents the mixing of water masses and limits oxygen diffusion from the atmosphere to the hypolimnion (Wetzel 1983) which creates an oxygen-depleted zone that

\section{Editorial Handling: Wilfired Winkler.}

Akram El Kateb

akram.elkateb@unifr.ch

1 Department of Geosciences, University of Fribourg, Chemin du Musée 6, 1700 Fribourg, Switzerland

2 Federal Office of Public Health FOPH, Radiation Protection, Schwarzenburgstrasse 157, 3003 Bern, Switzerland affects the fish community in a negative way (Hecky et al. 1994). Technical developments like so-called aerators placed at the lake bottom (Lackey 1972) were installed to reduce or prevent the natural oxygen depletion of the hypolimnion.

Wind-generated surface waves produce turbulences in the mixed surface layer and generate vertical current (Monismith and MacIntyre 2009). Many studies on wind action were performed to determine their effect on mixing and stratification of the water masses (Sarraf et al. 1988), however, the main approach used is based on numerical models (e.g. Sarraf et al. 1988; Podsetchine and Schernewski 1999; Hodges et al. 2000; Botte and Kay 2002; Koçyigit and Falconer 2004) predicting the water mass behaviour along a lake transect (cross section). Predicting wind-induced behaviour of water masses in lakes is not straightforward because of (1) the transfer of energy and momentum at the interface of two media where a large density gradient occurs. (2) The substantial variation and reversal of the vertical component of the velocity produced by the wind action. (3) Temporal changes in horizontal amplitude and direction (Sarraf et al. 1988).

High resolution monitoring data of water temperature and dissolved oxygen were collected from April to 
September 2015 at $20 \mathrm{~m}$ depth in Lake Murten. This dataset is compared to atmospheric parameters (e.g. atmospheric temperature, wind speed, atmospheric pressure, and precipitation) to better understand the wind impact on Lake Murten and the seasonal variations of water mass stratification documented by the SEn (Environmental Service of Fribourg).

\section{Study site}

Lake Murten is a relatively small lake compared to e.g. Lake Léman, Lake Neuchâtel, and Lake Lucerne, located in the western part of Switzerland (Fig. 1). Its total surface is about $22.8 \mathrm{~km}^{2}$ with a length of $8.15 \mathrm{~km}$ and a width of $2.8 \mathrm{~km}$. The maximal water depth reaches $45.5 \mathrm{~m}$ whereas the mean depth is $23.3 \mathrm{~m}$ (Reymond and Straub 1993).

Based on the revised classification of Lewis Jr (1983), Lake Murten is a warm monomictic lake having no seasonal ice cover, a stable stratification throughout the year with winter mixing occurring once a year. This characteristic has a major impact on the dissolved oxygen content during the year and therefore, on the distribution of organisms (Bonhomme 2008). The turnover of water masses in Lake Murten generally occurs in winter between December and January. When the water masses are not stratified, the stress applied by winds blowing on the lake surface allows water mixing and oxygenation of the entire water column (Bonhomme 2008). Water mass stratification establishes due to higher air temperatures (Boehrer and
Schultze 2008) following seasonal cycles. It induces an isolation of the hypolimnion and prevents gas exchanges between the atmosphere and the deeper part of the water column. Biological and/or microbiological processes consume oxygen within the hypolimnion and induce oxygen reservoir depletion.

The SEn investigated Lake Murten for several years. Once a month, the SEn deploys a multiparameter probe for water quality monitoring at the deepest point of the Lake (Fig. 1) to obtain profiles of the following parameters: water depth, temperature, electrical conductivity, transparency, $\mathrm{pH}$ and dissolved oxygen. Water samples are collected for chemical and biological analyses. The SEn (http://www.die3seen.ch) observed water mass stratifications during Springs (generally May) until the beginning of Winters (December). Water mass stratification set on during March with the formation of the epilimnion within the top five to seven meters of the water column and of the hypolimnion from approximately $20 \mathrm{~m}$ depth down to the lake bottom. The difference between surface water temperatures (SWT) and bottom water temperatures (BWT) increases from Spring to Summer (e.g., SWT up to $25^{\circ} \mathrm{C}$, BWT at $6{ }^{\circ} \mathrm{C}$ in August 2015). In September, the water mass stratification starts to change: first SWT decreases, followed by a thickening of the epilimnion reaching a depth of $30 \mathrm{~m}$ during December 2015. Due to cold air temperatures, the stratification disappears creating a homothermal water column in January 2016 (http://www. die3seen.ch).
Fig. 1 Map of Lake Murten with isobaths, the location of water profile performed every month by the SEn

(Environmental Service of Fribourg) (A) and the position of the Lander System (B). Location $\mathrm{C}$ on the map insert represents the MeteoSwiss meteorological station in Payerne

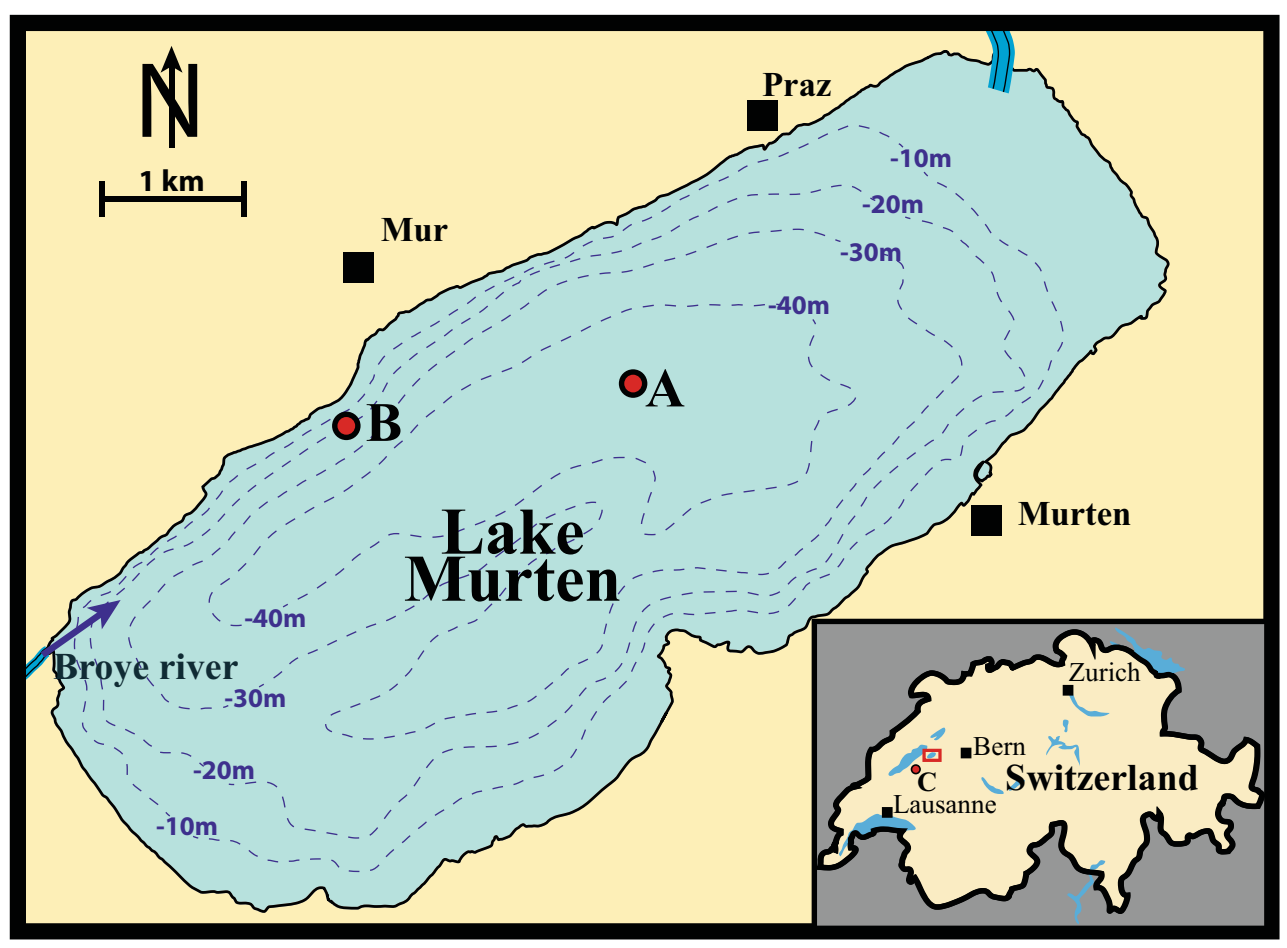




\section{Material and method}

\subsection{Multiprobe Lander System}

A multi-probe Lander System to measure water parameters (water temperature, $\mathrm{pH}$, dissolved oxygen and electrical conductivity) in shallow water (e.g., marine, lacustrine or riverine) was assembled at the department of Geosciences, University of Fribourg (Switzerland) (Fig. 2). The Lander System is composed by an aluminium frame including a tripod, which supports all components: a waterproof case with the data logger, an additional waterproof case for the batteries and four sensors (Fig. 2).

- The temperature sensor type 107 from Campbell Scientific consists of a thermistor encapsulate in an epoxy-filled aluminium housing, it has an accuracy of $\pm 0.2{ }^{\circ} \mathrm{C}$ at a range of -0 to $50{ }^{\circ} \mathrm{C}$.

- For conductivity was used the EC250 Electrical conductivity (EC) sensor from Pentair. It has an autonomous temperature sensor, which allows the normalisation of the values at $25{ }^{\circ} \mathrm{C}$ and delivers accuracy for conductivity at $1 \%$ of the full-scale value between 0 and $30^{\circ} \mathrm{C}$ covering the range $0-70,000 \mu \mathrm{S} /$ $\mathrm{cm}$.

- The digital pH sensor CS526 ISFET (Campbell Scientific) operates in up to $70 \mathrm{~m}$ water depth with an accuracy of $\pm 0.1 \mathrm{pH}$ units. Its operating temperature range corresponds to $0-40{ }^{\circ} \mathrm{C}$. All $\mathrm{pH}$ measurements are temperature compensated.

- The dissolved oxygen sensor CS512 of Campbell Scientific converts electrical current produced by a chemical reaction at the sensors cathode into a millivolt output proportional to the dissolved oxygen value (DO) in water ranging from 0 to $50 \mathrm{mg} / \mathrm{L}$. It operates between 0 and $40{ }^{\circ} \mathrm{C}$ at a pressure up to 2 bars. Its accuracy is $\pm 0.2 \mathrm{mg} / \mathrm{L}$.

Two different configurations of the Lander System were used in Lake Murten, one with the data cable attached to the buoy and the other with the data cable and the batteries attached to the buoy. This study focuses on water temperature and dissolved oxygen concentrations from $20 \mathrm{~m}$ water depth at the northwestern part of the Lake Murten in front of the village of Mur (Fig. 1). The Lander system was deployed at this position because the depth of $20 \mathrm{~m}$ corresponds to the transition from the metalimnion to the hypolimnion layers; the steep slopes at the northwestern part of the lake allow to reach $20 \mathrm{~m}$ depth close to the shore (Fig. 1); the Broye river (Fig. 1) supplies runoff from $63 \%$ of the drainage basin into Lake Murten (Liechti 1994) at approximately 2 km SouthWest of the Lander System position.

Data of water parameters were collected from 9th of April to 10th of September 2015 (Fig. 3); however, gaps in
Fig. 2 a Technical sketch of the Lander System with its different components (sensors, tripods aluminium frame, datalogger). b Photograph of the Lander System not equipped with the conductivity sensors. c Two different configuration of the Lander System were used during mesurements. On the left, the waterproof case with the batteries is placed directly on the Lander System making necessary to recover it for battery changes. On the right, the waterproof case with the batteries is place on the buoy allowing batteries changes without recovery of the Lander System

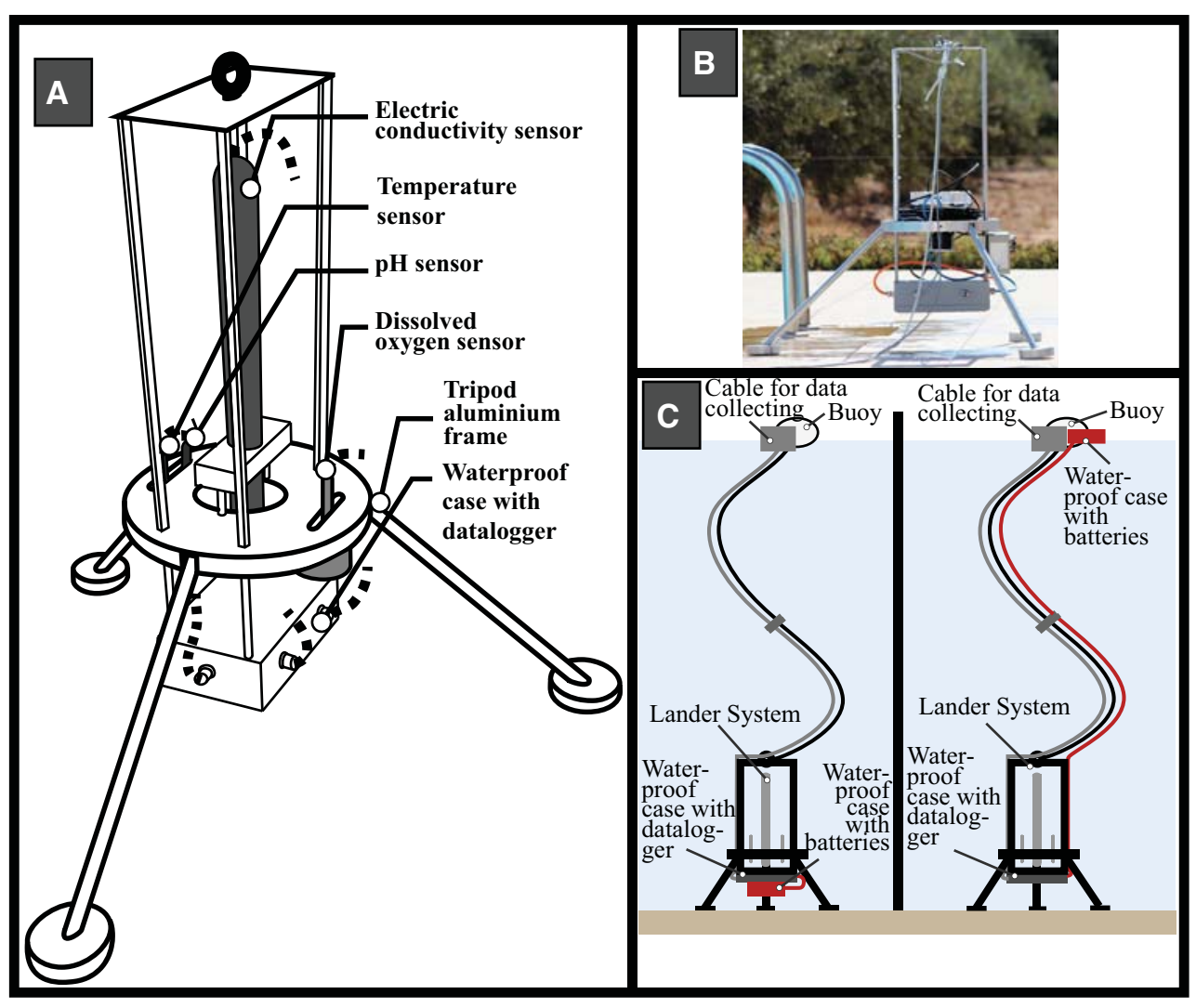




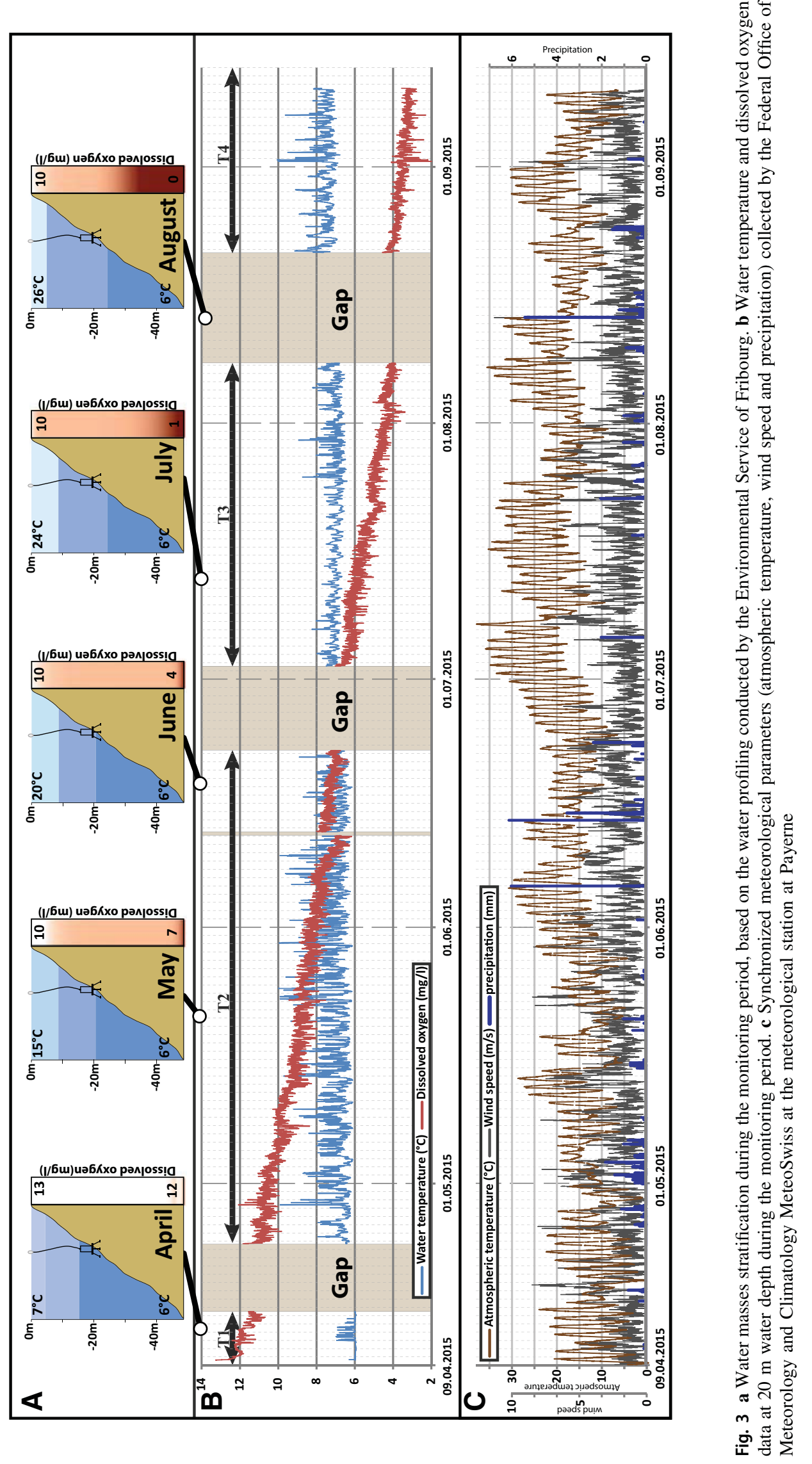



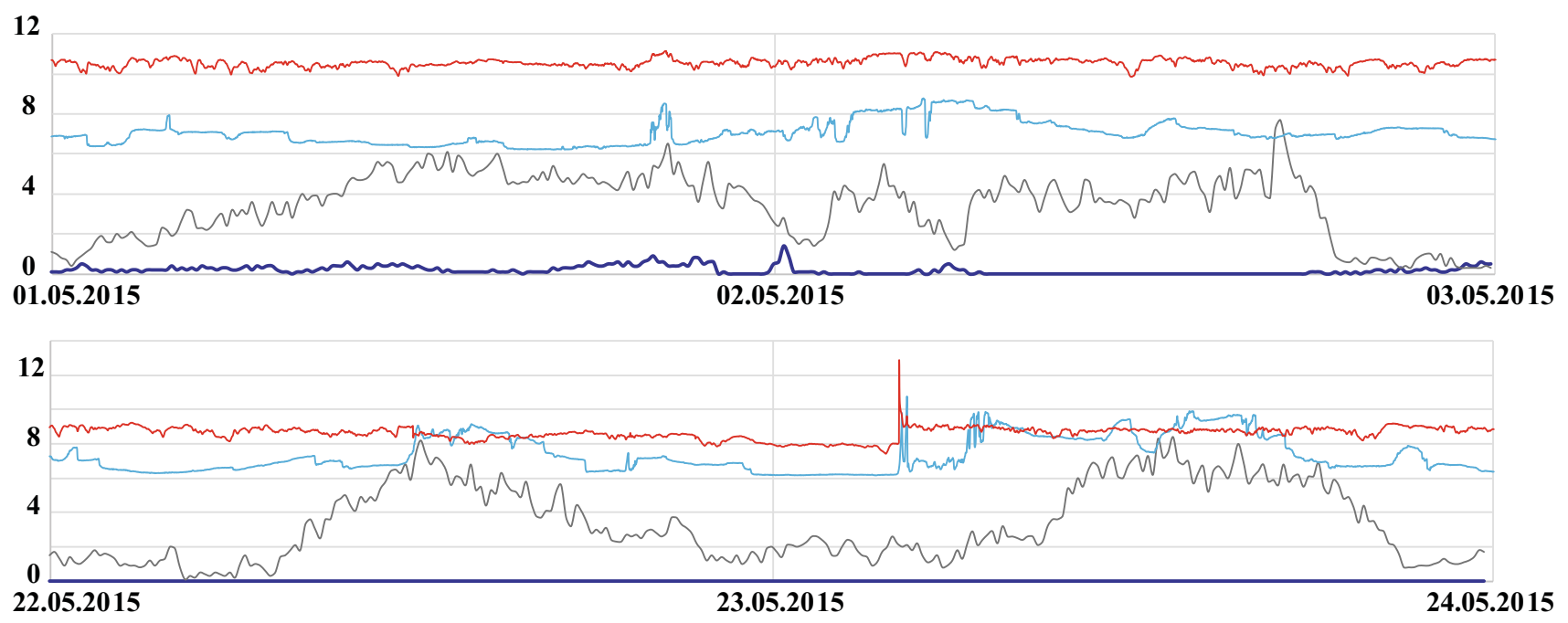

12

8

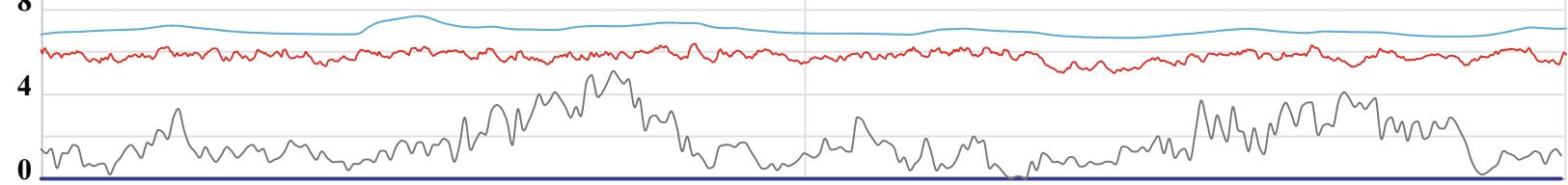

12.07.2015

13.07.2015

14.07.2015

12

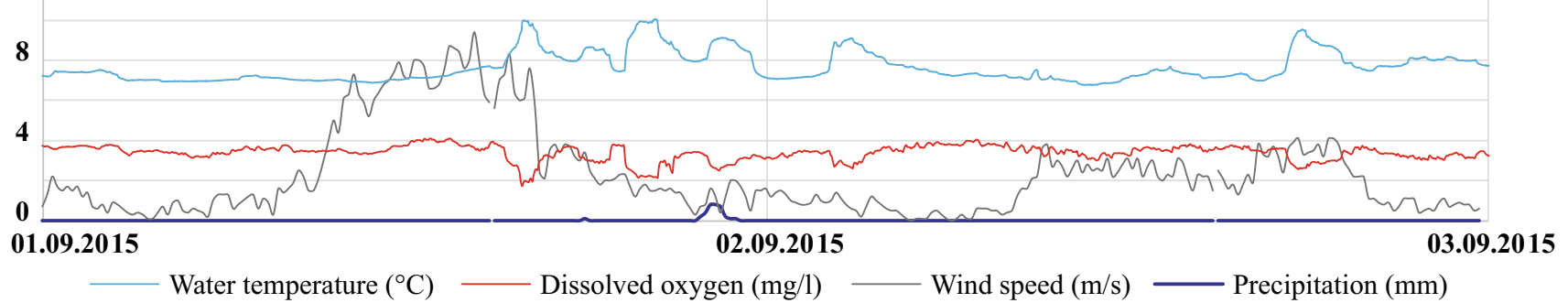

Fig. 4 Close up of the Lander System, wind speed and precipitation data between 1st to 3rd of May, 22nd to 24th of May, 12th to 14th of July, 1st to 3rd of September 2015, respectively

the record (15th of April to 23rd of April, 22nd of June to 2nd July and 8th August to 21st of August) represent the periods of the Lander System maintenance (e.g. change of batteries and sensor cleaning). Every $30 \mathrm{~s}$, water temperature and dissolved oxygen was measured and the dataset (Fig. 4) was synchronized to atmospheric parameters (e.g. wind speed, precipitation and atmospheric temperature) collected by the Federal Office of Meteorology and Climatology MeteoSwiss at the meteorological station at Payerne (Fig. 1). Considering gaps in records and the period of measurements, four time intervals are delimited (Fig. 3): T1: 09th of April to 15th of April 2015; T2: 23rd of April to 22nd of June 2015; T3: 2nd of July to 8th of August 2015; 21st of August to 10th of September 2015.

\subsection{Fourier, continuous wavelet and cross wavelet transform}

Mathematical analysis of the dataset tested our hypothesis on the air-lake interaction based on the first observation of the collected measurements with the Lander System. The discrete Fourier transform (DFT) and cross wavelet transform were performed on water temperature and wind speed data set.

Fourier transform was performed using Spectra software 1.13 (Nuhertz) available at http://www.nuhertz.com/soft ware. It allowed to resolve frequencies with highest intensities for both water temperature and wind speed for the intervals T2-T4 (Fig. 5). Time series analysis was performed using the MatLab wavelet software package (WTC-R17，02 Sep 2014) of Grinsted et al. (2004), 


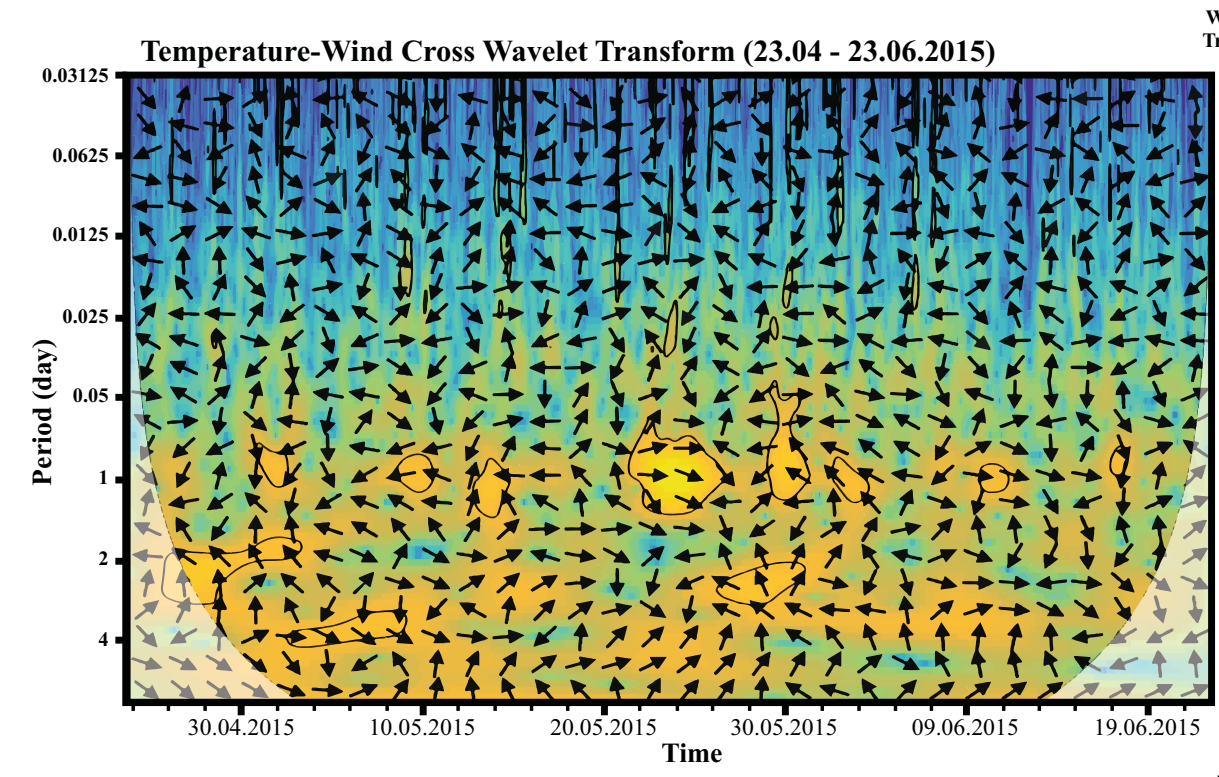

Wind \& Temperature Fourier

ransform (23.04 - 23.06.2015)

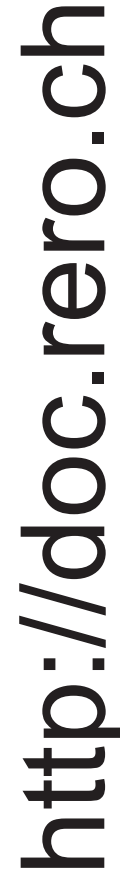

Temperature-Wind Cross Wavelet Transform (02.07-08.08.2015)

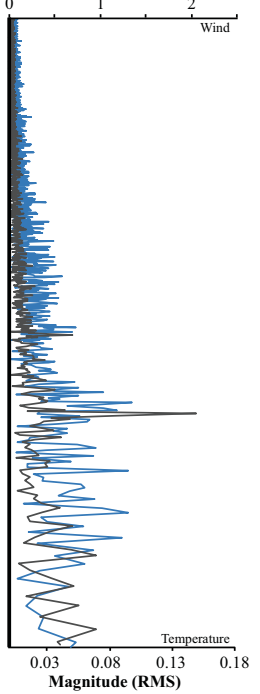

Wind \& Temperature Fourier
Transform (02.07 - 08.08.2015)
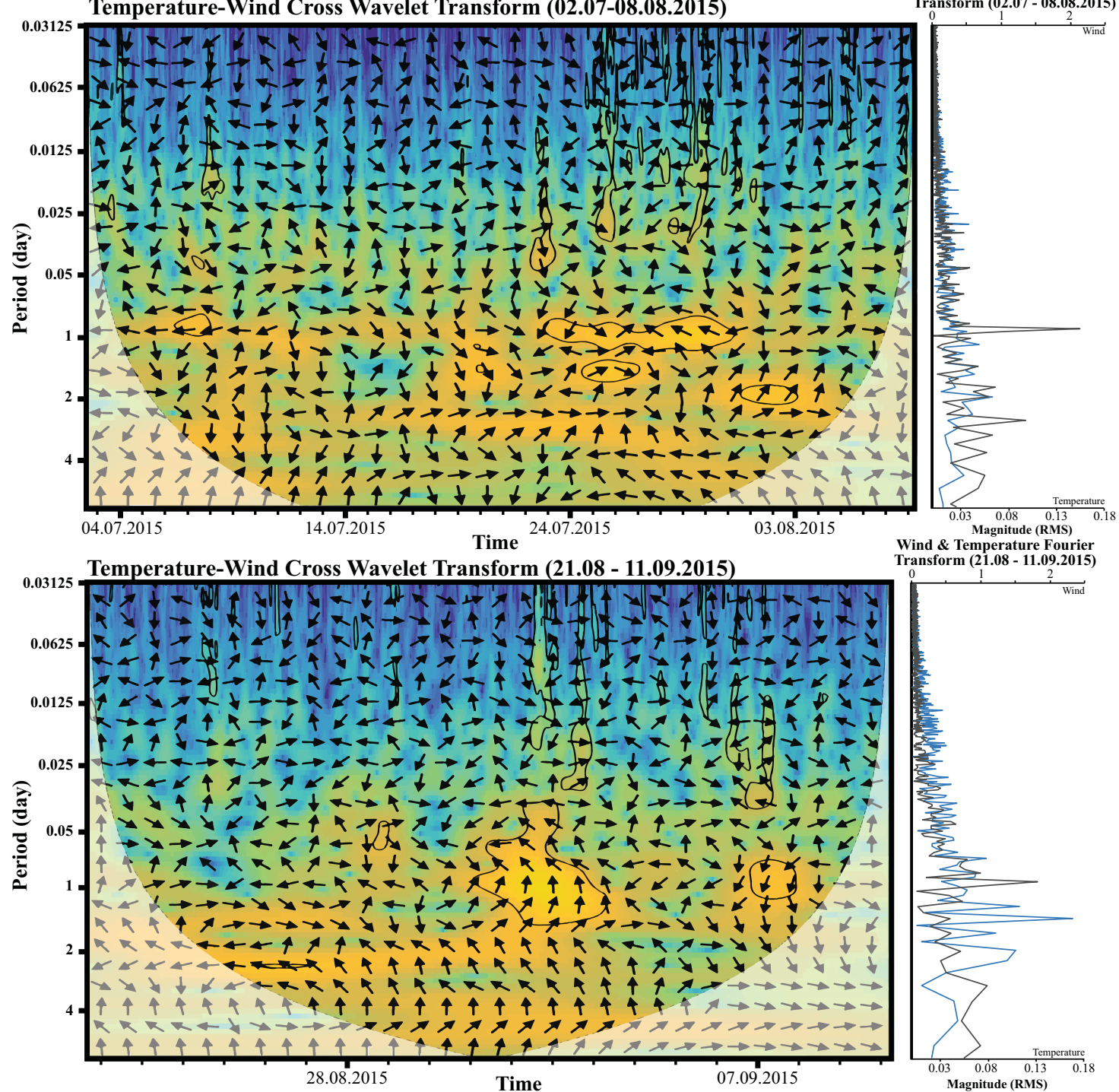
Transform (21.08 - 11.09.2015) 
4Fig. 5 Graphical representation of Fourier transform and cross wavelet transform (water temperature and wind speed) for the $\mathrm{T} 2$, $\mathrm{T} 3$ and T4 time intervals. The thick contour designates the 5\% significance level against red noise and the cone of influence (COI) where edge effects might distort the picture is shown as a lighter shade. Phase arrows indicate the relative phase relationship between the series (pointing right: in-phase; left: anti-phase; down: temperature leading wind speed by $90^{\circ}$, up: wind speed leading temperature by $90^{\circ}$ )

available at http://noc.ac.uk/marine-data-products/crosswavelet-wavelet-coherence-toolbox-matlab. Prior to analysis, the measurements of temperature and wind speed were reduced to a resolution of $10 \mathrm{~min}$. The cross wavelet transform (XWT) is a useful method for analysing the coherency and phase relationships between two time series (here: water temperature and wind speed) as a function of frequency (Grinsted et al. 2004). It creates a figure of cross wavelet power in units of normalized variance. Monte Carlo techniques were used to assess the statistical significance level (5\%, thick lines in Fig. 5) against a red noise background.

\section{Results}

A general increase of daily minimum temperature was observed during the whole record: (1) at the beginning of April 2015, daily minimum water temperature was around $6{ }^{\circ} \mathrm{C}$ but in September, the water temperature reaches around $7{ }^{\circ} \mathrm{C}$. (2) A significant decrease of dissolved oxygen from $13 \mathrm{mg} / \mathrm{L}$ in April to less than $3 \mathrm{mg} / \mathrm{L}$ in September was observed during the monitoring period (Fig. 3).

In addition to a daily fluctuation of the atmospheric temperature, a general increase is observed between April and July 2015. However, the month of July 2015 is characterised by summer temperature $\left(>30^{\circ} \mathrm{C}\right)$ with fluctuation at the beginning of August.

The record of water temperatures at $20 \mathrm{~m}$ depth shows daily fluctuations with significantly varying amplitudes

Table 1 Rate dissolved oxygen decrease depending on the time interval

\begin{tabular}{ll}
\hline Time interval & $\begin{array}{l}\text { Rate of dissolved } \\
\text { oxygen decrease } \\
\text { (mg/day) }\end{array}$ \\
\hline 09 April 2015-08 May 2015 & 0.079 \\
09 May 2015-08 June 2015 & 0.065 \\
09 June 2015-08 July 2015 & 0.044 \\
09 July 2015-08 August 2015 & 0.072 \\
21 August-10 September 2015 & 0.049 \\
\hline
\end{tabular}

(Figs. 3, 4). Highest thermal amplitude of up to $4{ }^{\circ} \mathrm{C}$ within a few hours was reached at the end of April (28th April 2015). The second half of May was still characterised by high thermal fluctuation, reaching minimum values of $\Delta \mathrm{T} \leq 1{ }^{\circ} \mathrm{C}$ during end of June until end of July. Temperature variations increase again to a value of $\Delta \mathrm{T}=3{ }^{\circ} \mathrm{C}$ in the beginning of August 2015 until the end of the monitoring period.

Dissolved oxygen decreased through the entire record. However, the decreasing rate was discontinuous and irregular, but reached significantly higher rates during April and July (Table 1), exceeding $0.072 \mathrm{mg} /$ day, whereas it never reached values above $0.049 \mathrm{mg} /$ day during June or August. Daily fluctuations of dissolved oxygen at $20 \mathrm{~m}$ water depth were much higher but never exceeding $1 \mathrm{mg} / \mathrm{L}$. Brief events with significant changes in dissolved oxygen were noticed. Indeed, for a few days (2-3 days) the decrease in dissolved oxygen was more pronounced in comparison to the general trend. These events have been recorded during five periods: 7th-8th May; 22nd-23rd May; 7th-10th June; 20th-23rd July; and 1st-3rd August 2015 (Figs. 3, 4).

Daily fluctuations of the wind speed generally occurred, however, long windy events (2-3 days) have been recorded between the 8th and 10th of June; the 7th and 8th of July: and the 27th and 28th of July 2015 (Fig. 3). Maximum wind speeds were reached on the 1st of September 2015 (Figs. 3, 4) with almost $10 \mathrm{~m} / \mathrm{s}$, but generally higher wind speeds occurred during Spring (T2) than during Summer (T3) (Fig. 3). The precipitation record during the monitoring period indicates one phase of high $(>2 \mathrm{~mm} / 10 \mathrm{~min}$ ) and continuous rainfall between the 30th April and 6th May 2015. Several events of more intense rainfall of up to $5 \mathrm{~mm} / 10 \mathrm{~min}$ occurred during the 5th and 13th June, as well as on 13th August 2015.

Discrete Fourier transform (DFT) on the water temperature data show higher magnitude for periods equal or higher than 1 day for all three time intervals T2, T3 and T4 (Fig. 5) with slightly lower values for the summer (T3, Fig. 5) and highest values in August/September (T4, Fig. 5). The DFT on wind speed data shows similar results for all the time intervals and reaches much higher magnitudes for the period of 1 day compared to temperature (Fig. 5).

The temperature-wind cross wavelet transform (XWT) for the time interval $\mathrm{T} 2$ indicates a strong interaction between the wind speed and the water temperature especially between the 22nd and 24th May 2015 (Fig. 5). The black arrows in the XWT of T2 highlight that water temperature and wind speed are in phase with a slight lead of the wind speed.

Despite the high intensity of wind speed during the time interval T3, the XWT shows only a weak coherency 
between the phase relation of wind speed and water temperature. Only in the period between 22nd July and 1st August both parameters show a strong relation and are in phase (Fig. 5).

The XWT indicates a strong coherency of the phase relation between temperature and wind speed with a strong lead of the wind speed during time interval T4 (Fig. 5).

\section{Discussion}

\subsection{Lake stratification and water temperature fluctuation}

Thermal variation at the Lander System position was initially related to the proximity of the Broye river inflow (Fig. 1). However, data processing with wavelet transforms clearly indicate the consistency between the water temperature at $20 \mathrm{~m}$ depth and wind speed at the lake surface. Surface turbulence generates mixing at depths depending on water mass stratification. Intense surface turbulences generated by wind reached at least a depth of $20 \mathrm{~m}$. Unfortunately, the data set does not allow the estimation of size and location of this convection cell, one of the several occurring in Lake Murten under the influence of strong winds (e.g., Bise). Based on our data set collected with the Lander System and the water profiles performed by SEn every month, two configurations of water masses in Lake Murten can be described:

1. Low stratification occurring in Spring and Autumn, when the water temperature gradient between the lake surface and bottom is relatively small (Fig. 3). The wind generates surface turbulence reaching at least the depth of the Lander System. Significant water temperature fluctuations up to $4{ }^{\circ} \mathrm{C}$ within a few hours have been documented (Fig. 3).

2. High stratification occurring in Summer. The water temperature gradient between the lake surface and bottom is very large and reaches $\sim 18{ }^{\circ} \mathrm{C}$ (Fig. 3). The correlation between the wind speed and the water temperature at $20 \mathrm{~m}$ depth is weak. Wind-related turbulences at the lake surface are not strong enough to reach $20 \mathrm{~m}$ of water depth.

Discrete Fourier transform on the wind speed data indicate daily period as the main frequency. Thermal atmospheric amplitude may have an effect on the wind speed in this region of Switzerland, but their frequency and magnitude were relatively constant during the monitoring period, which was not the case for the water temperature. The high stratification of the lake prevented the energy transfer of the wind-induced surface turbulence downwards deeper parts.
The cross wavelet transforms clearly confirm that the wind speed intensity generates thermal fluctuations at $20 \mathrm{~m}$ depth. A time lag of $12-20 \mathrm{~h}$ has been measured with the wind speed leading the bottom water temperature at $20 \mathrm{~m}$ depth. The time lag corresponds to the distance the surface turbulences needs to reach the depth of the Lander System resulting in a speed $1-1.6 \mathrm{~m} / \mathrm{h}$. Wind direction is an additional factor, which could influence the formation of the lake surface turbulence. The orientation of the wind direction is constant during the monitoring period with a North-Est to South-West axis (Fig. 6). However, the wind direction may vary depending to the season: In WinterSpring the main wind direction is from North-East to South-West corresponding to the Bise and in SummerAutumn the wind direction is reverse from South-West to North-East. Thus, a main orientation of the wind direction contributes to increase the stress applied on the lake surface and to amplify the surface turbulence.

\subsection{Water masses stratification and dissolved oxygen depletion}

Atmospheric thermal amplitude between Winter and Summer induce water-mass stratification (Boehrer and Schultze 2008), which isolates the hypolimnion from the upper part of the water column and due to stratification; the hypolimnion is less influenced by atmospheric condition.

The monitoring period (April 2015-September 2015) at Lake Murten corresponds to times with a water mass stratification and separation of the meta-/hypolimnion from the epilimnion. This directly impacts e.g., the dissolved oxygen. The position of the Lander System at $20 \mathrm{~m}$ allows to identify changes in the hypolimnion especially the continuous depletion of dissolved oxygen (Fig. 3). Isolated from the lake surface no gas exchange with the atmosphere is possible and the planktonic organic material is mineralized and decomposed consuming dissolved oxygen in the hypolimnion (Laboratoire du Service des Eaux, Sols et Assainissement 2011).

The rate of oxygen consumption can also be influenced by biological factors (e.g., planktons, fishes) or microbiological activities (e.g., organic matter mineralisation by microbial activities). During March and April 2015 a significant increase in diatom concentration that may be considered as a bloom compared to the rest of the year occurred (http://www.die3see.ch). Diatoms are able to photosynthesise and are important oxygen producer. The rate of photosynthesis in diatoms depends on e.g., light intensity, water temperature and carbon dioxide concentration (Barker 1935). At the end of the Spring, lower solar radiation with respect to intensity and duration can affect the balance between oxygen production (photosynthesis) and consumption (respiration) of diatoms. In addition, the 
Fig. 6 Wind Rose diagram for the meteorological station of Payerne showing relative number of wind observation for $360^{\circ}$ of the compass for the monitored period (9th of April to 10th of September). Lengths of arms of the Rose are proportional to frequency of windy event and the different colors represent the wind speed

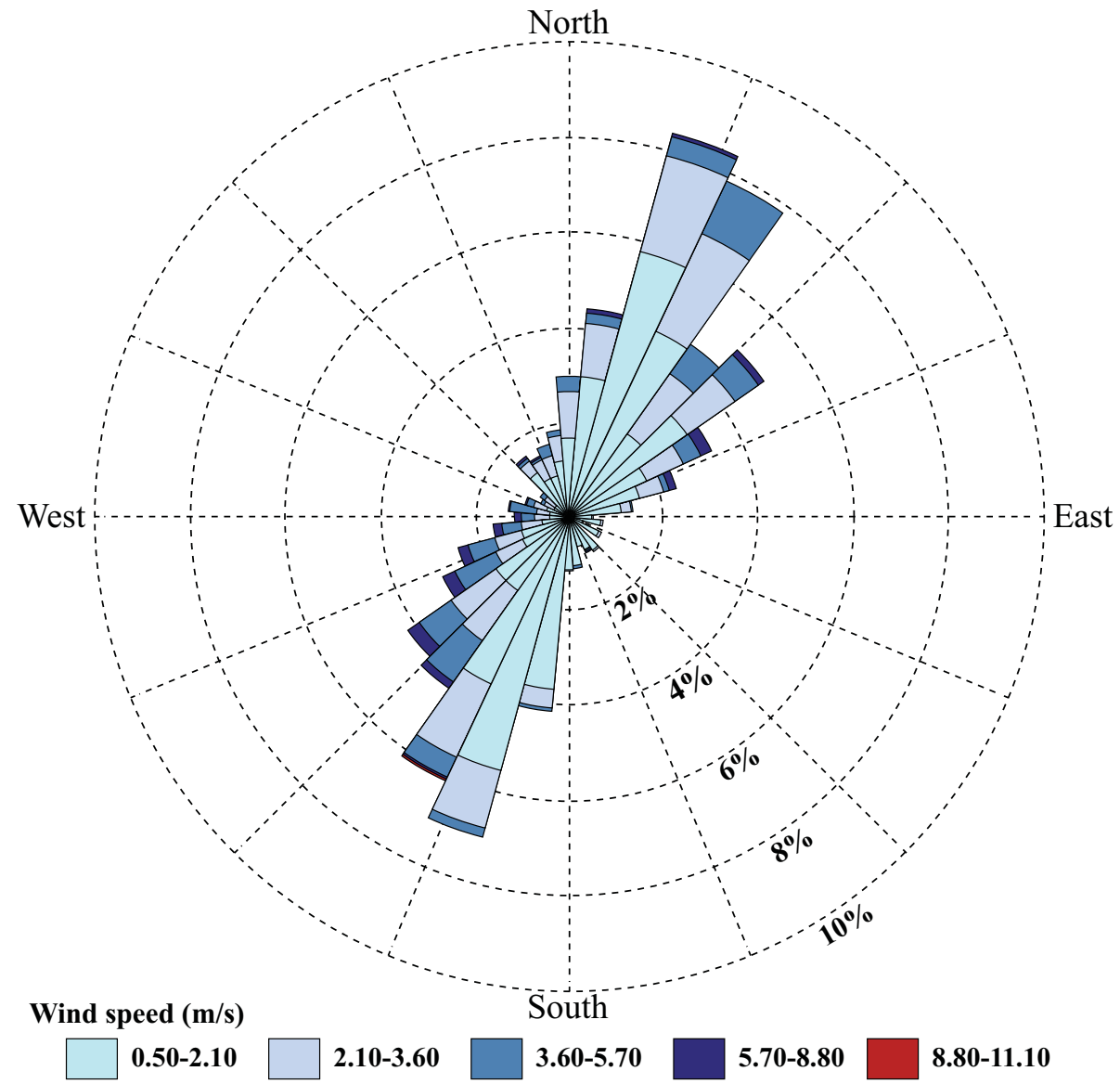

\section{Conclusion}

For the first time, prolonged high resolution water parameters monitoring performed in Lake Murten. The dataset provides valuable information on surface turbulences generated by winds in the lake. The stratification process in Summer 2015 affected water temperature and dissolved oxygen. Statistical coherence of water temperature at $20 \mathrm{~m}$ depth and wind speed allowed us to identify surface turbulence mixing processes.

Acknowledgements We gratefully acknowledge the Environmental Service of Fribourg (SEn) for their valuable studies during the years contributing to a better understanding of Lake Murten. We thank Pierre Schaer for his valuable help and for giving access to his boat for deployment, recovery and maintenance of the Lander System. We thank the Swiss National Science Foundation (SNSF) project 200021_149589 and the Department of Geosciences for providing financial and technical support. We acknowledge the editor Prof. Wilfried Winkler for his assistance and two anonymous reviewers for their valuable comments that helped to considerably improve this manuscript. 


\section{References}

Barker, H. A. (1935). Photosynthesis in diatoms. Archives of Microbiology, 6(1), 141-156.

Boehrer, B., \& Schultze, M. (2008). Stratification of lakes. Reviews of Geophysics, 46(2), 1-27.

Bonhomme, C. (2008). Turbulences et ondes en milieu naturel stratifié: deux études de cas: étude du mélange turbulent et des ondes internes du lac Pavin (Auvergne, France); influence des ondes de Rossby sur la concentration en chlorophylle de surface dans l'upwelling du Pérou (Doctoral dissertation, Paris Est). Ph.D. Dissertation, Université de Paris Est, Paris Est.

Botte, V., \& Kay, A. (2002). A model of the wind-driven circulation in Lake Baikal. Dyn Atmos Oceans, 35(2), 131-152.

Grinsted, A., Moore, J. C., \& Jevrejeva, S. (2004). Application of the cross wavelet transform and wavelet coherence to geophysical time series. Nonlinear Processes in Geophysics, 11(5/6), $561-566$.

Hecky, R. E., Bugenyi, F. W. B., Ochumba, P., Talling, J. F., Mugidde, R., Gophen, M., et al. (1994). Deoxygenation of the deep water of Lake Victoria, East Africa. Limnology and Oceanography, 39(6), 1476-1481.

Hodges, B. R., Imberger, J., Saggio, A., \& Winters, K. B. (2000). Modeling basin-scale internal waves in a stratified lake. Limnology and Oceanography, 45(7), 1603-1620.

Kirk, J. T. (1985). Effects of suspensoids (turbidity) on penetration of solar radiation in aquatic ecosystems. In B. R. Davies \& R. D. Walmsley (Eds.), Perspectives in Southern Hemisphere Limnology (pp. 195-208). Berlin: Springer.

Koçyigit, M. B., \& Falconer, R. A. (2004). Three-dimensional numerical modelling of wind-driven circulation in a homogeneous lake. Advances in Water Resources, 27(12), 1167-1178.
Laboratoire du Service des Eaux, Sols et Assainissement (2011). Bilan de santé du lac de Morat-Etat 2009-2011. Report for Vaud canton (SESA) (pp 1-10).

Lackey, R. T. (1972). A technique for eliminating thermal stratification in lakes. Water Resources Bulletin, 8(1), 46-49.

Lewis, W. M., Jr. (1983). A revised classification of lakes based on mixing. Canadian Journal of Fisheries and Aquatic Sciences, 40(10), 1779-1787.

Liechti, P. (1994). L'état des lacs en Suisse. Cahier de l'environnement, 237, 1-159.

Maciej Gliwicz, Z. (1986). A Lunar cycle in zooplankton. Ecology, 67(4), 883-897.

Monismith, S. G., \& MacIntyre, S. (2009). The surface mixed layer in lake and reservoirs. In G. E. Likens (Ed.), Biogeochemistry of Inland Waters (pp. 636-650). Boston: Academic Press.

Podsetchine, V., \& Schernewski, G. (1999). The influence of spatial wind inhomogeneity on flow patterns in a small lake. Water Research, 33(15), 3348-3356.

Read, J. S., Hamilton, D. P., Jones, I. D., Muraoka, K., Winslow, L. A., Kroiss, R., et al. (2011). Derivation of lake mixing and stratification indices from high-resolution lake buoy data. Environmental Modelling \& Software, 26(11), 1325-1336.

Reymond, O., \& Straub, F. (1993). Phytoplancton du lac de Morat en 1988-1989: comparaison avec les données antérieures. Bulletin de la Société neuchâteuloise des Sciences naturelles, 116(2), $55-64$.

Sarraf, S., Kahawita, R., \& Eljabi, N. (1988). 3-D General movable mesh in water circulation modeling. Journal of Computing in Civil Engineering, 2(2), 170-187.

Wetzel, R. G. (1983). Attached algal-substrata interactions: fact or myth, and when and how? In R. G. Wetzel (Ed.), Periphyton of Freshwater Ecosystems (pp. 207-215). New York: Springer. 